\title{
Beneficial Effects of Solid Matrix Chemo-priming in Okra
}

\author{
K. E. Conway and R. Mereddy, Department of Entomology and Plant Pathology; B. A. Kahn and Y. Wu, De- \\ partment of Horticulture and Landscape Architecture; and S. W. Hallgren and L. Wu, Department of Forestry, \\ Oklahoma State University, Stillwater 74078
}

\begin{abstract}
Conway, K. E., Mereddy, R., Kahn, B. A., Wu, Y., Hallgren, S. W., and Wu, L. 2001. Beneficial effects of solid matrix chemo-priming in okra. Plant Dis. 85:535-537.

Two field trials at Stillwater and Bixby, OK, evaluated the efficacy of solid matrix priming techniques, alone or in combination with fungicide seed treatment on seedling emergence and reduction of damping-off of okra in field soil naturally infested with Pythium ultimum. The following treatments were evaluated: thiram + carboxin (chemo-primed) (commercially applied), biological seed treatment (bio-primed) (Trichoderma harzianum isolate OK-110, $1 \mathrm{~g}$ suspended in $1 \%$ carboxymethylcellulose $[\mathrm{CMC}]$ ), untreated seed (control), and a $1 \% \mathrm{CMC}$ control. Chemo-primed seeds had a more uniform and faster emergence compared with untreated seeds at both field sites. Within 3 days, 92 and $78 \%$ of chemo-primed seeds had emerged at Stillwater and Bixby, respectively, compared with 84 and $71 \%$ emergence in the untreated control. Mean emergence of chemo-primed seeds was lower $(P \leq 0.05)$ than the untreated control. Chemo-primed seeds had greater vigor $(P \leq 0.05)$ at both locations compared with either fungicide-treated or priming alone, at both locations. There were no differences $(P \leq 0.05)$ in yield among treatments at both locations. P. ultimum was consistently isolated from damped-off seedlings and surrounding soil at both locations. Isolates of P. ultimum were more pathogenic on okra in laboratory tests than isolates of Rhizoctonia spp., Fusarium spp., and other Pythium spp. also isolated from seed or soil.
\end{abstract}

Additional keywords: bio-priming, emergence rate, seed vigor

Okra is planted on about 260 ha $(650$ acres) in Oklahoma and has a value of $\$ 2$ million annually (J. E. Motes, Department of Horticulture \& Landscape Architecture, Oklahoma State University, Stillwater, personal communication). Delayed and erratic germination creates problems with fertilizer utilization, postemergence weed control, and uniform harvesting (16). The hard seed coat of okra is a major physiological constraint to uniform stand establishment and performance $(12,16)$. Environmental factors such as inadequate or excessive soil moisture, low soil temperatures, crusting of soil, and preemergence damping-off caused by Pythium spp. also contribute to erratic gemination of okra seed.

Since environmental factors often cannot be controlled, modification of the seed by either biological, chemical, or physiological techniques should be evaluated to improve the vigor of the seedling and uniformity of stand. Solid matrix priming (SMP) is a technique developed by John Eastin (7). In SMP, a solid matrix is used to regulate water imbibition by seeds. SMP

Corresponding author: K. E. Conway

E-mail: kenncon@okstate.edu

Accepted for publication 2 February 2001.

Publication no. D-2001-0312-03R

(C) 2001 The American Phytopathological Society alone (15) or in combination with fungicides $(2,9)$ or biological agents $(4,8)$ has improved the rate and uniformity of emergence of vegetable seeds and reduced damping-off diseases (8). We evaluated 10 solid carriers as priming agents to improve seedling vigor of okra (13) and pine (18). We found that clay carriers consistently improve seedling vigor compared with humic acid or cellulosic formulations. In this study, we evaluated combinations of seed priming with either fungicide or biological treatments to reduce damping-off disease in field-planted okra seed. The term chemo-priming is used to indicate that fungicide-treated seeds rather than untreated seeds were used in the priming process. In bio-priming, untreated seeds were primed and $1 \mathrm{~g}$ of biological formulation was applied to the seeds using $1 \%$ carboxymethylcellulose (CMC).

\section{MATERIALS AND METHODS}

Chemo-priming. Fifty okra seeds cv. Clemson Spineless with the standard fungicide treatment consisting of thiram plus carboxin, $113.4 \mathrm{~g}$ per $45.4 \mathrm{~kg}$ ( $4 \mathrm{oz}$ per 100 lb) of seed (commercially applied by $\mathrm{Ab}$ bott \&Cobb Seed Co., 4120 West Pecan St., McAllen, TX) were placed in a selfsealing polyethylene bag containing the SMP agent clay-carri-all (CCA) (crystalline quartz, $\mathrm{pH}$ 7.4; American Colloid Co., Arlington Heights, IL). Water had been added to the SMP to provide $50 \%$ water content $(-0.7 \mathrm{mPa}$ water potential). The ratio of SMP to seeds was 3:1 (wt/wt). Treatments were replicated four times for a total of 200 seeds. The contents of the bag were thoroughly mixed, and the bags were incubated at room temperature for 3 days. These amounts and conditions had been established in previous research (13). Seeds were separated from the SMP agent by sieving, allowed to dry overnight, and placed in paper bags for transport to the field.

Bio-priming and seed coating. Fifty untreated okra seeds cv. Clemson Spineless (Abbott and Cobb Seed Co.) were primed with heat-treated $\mathrm{CCA}\left(140^{\circ} \mathrm{C}, 24 \mathrm{~h}\right)$ at $50 \%$ water content $(-0.7 \mathrm{mPa}$ water content). After priming, seeds were spread on aluminum foil and dried overnight on a lab bench and then coated with a formulation of Trichoderma harzianum isolate OK-110 from soil in Stillwater, OK, by suspending $1 \mathrm{~g}$ of the formulation in $1 \%$ CMC. A dry formulation of T. harzianum (6) was used which contained a mixture of conidia, hyphal fragments, and chlamydospores and provided approximately $10^{6} \mathrm{CFU} / \mathrm{ml}$. Four replications of 50 seeds each were prepared and dried overnight. The CMC control was prepared by coating untreated seeds in $1 \%$ $\mathrm{CMC}$ and drying overnight.

Field trials. Planting was conducted at two sites to evaluate six seed treatments: 1 , untreated seed; 2, fungicide-treated seed (thiram + carboxin); 3 , primed seed with no fungicide; 4, chemo-primed seed; 5, bio-primed seed; and 6, primed seed coated with $1 \% \mathrm{CMC}$. The first planting site was at the plant pathology research farm in Stillwater, and the second site was at the Department of Horticulture \& Landscape Architecture Vegetable Research Experiment Station at Bixby, OK. Each treatment had 50 seeds with four replications, and treatments were arranged in a completely randomized design. The plots were disked and fertilizer was applied according to standard agricultural practices for okra as recommended by the Oklahoma State University soil testing laboratory. Plots consisted of 24 rows $5 \mathrm{~m}$ long separated by 2 $\mathrm{m}$ alleys. At both locations, seeds were planted with a manually operated belt seeder calibrated to place the seed at a depth of $4 \mathrm{~cm}$. Seeds were planted on 17 May at Stillwater and on 19 May at Bixby. Emerging seeds were marked with plastic coffee stirrers. Seeds were considered emerged when hypocotyls were above the soil surface. Subplots, $3 \mathrm{~m}$ long, were established in each row 3 to 4 weeks after 
emergence by thinning plants to leave approximately 15 plants per row. These subplots were harvested repeatedly by hand for yield data (number and weight of pods per subplot). Thus, any difference in yield after thinning could not be attributed to stand variation. There were 14 to 15 picks for harvest at each location. Okra was harvested by hand at intervals of 2 to 3 days at both locations, and the number and weight of Okra was recorded from subplots.

Isolation of fungi from seedlings and soil. Diseased okra seedlings and surrounding soil were collected randomly from all plots. Seedlings were washed under running tap water for $5 \mathrm{~min}$ to remove all soil debris, rinsed with sterile water, blotted dry with sterile paper towels, and roots were plated onto potato dextrose agar (PDA). Representative fungal colonies were hyphal-tipped to selective media for identification. Pathogenicity of isolates was tested in growth chambers (16/8 h, light/dark cycle, $25^{\circ} \mathrm{C}$ ). Plastic pots, 7.6 $\mathrm{cm}$ (3 in), were filled with soilless mix (Fafard Potting Soil Mix, Conrad Fafard, Inc., Aquawam, MA) with $15 \%$ moisture. A centrally located hole was made with a

Table 1. Effects of seed treatment on mean emergence (ME), vigor index, and stand of okra at Stillwater, OK

\begin{tabular}{|c|c|c|c|c|}
\hline \multirow[b]{2}{*}{ Treatment $^{y}$} & \multicolumn{2}{|c|}{ Stand $(\%)$} & \multirow[b]{2}{*}{ Vigor index ${ }^{z}$} & \multirow[b]{2}{*}{ ME (days) } \\
\hline & 3 days $^{z}$ & 8 days $^{z}$ & & \\
\hline Chemo-primed & $91.5 \mathrm{a}$ & $88.5 \mathrm{a}$ & $54.3 \mathrm{a}$ & 1.9 \\
\hline Primed & $84.5 \mathrm{~b}$ & $80.5 \mathrm{~b}$ & $45.8 \mathrm{bc}$ & 2.1 \\
\hline Treated & $91.5 \mathrm{a}$ & $87.5 \mathrm{a}$ & $48.6 \mathrm{~b}$ & 2.0 \\
\hline Untreated & $84.1 \mathrm{~b}$ & $87.5 \mathrm{a}$ & $44.8 \mathrm{bc}$ & 2.2 \\
\hline CMC & $81.5 \mathrm{~b}$ & $86.0 \mathrm{a}$ & $43.4 \mathrm{bc}$ & 2.2 \\
\hline Bio-primed & $80.0 \mathrm{~b}$ & $77.0 \mathrm{~b}$ & $42.5 \mathrm{c}$ & 2.2 \\
\hline $\operatorname{LSD}(P \leq 0.05)$ & $\ldots$ & $\ldots$ & $\ldots$ & 0.2 \\
\hline
\end{tabular}

y Except for untreated control, all others were primed with the solid matrix clay-carri-all (CCA) at $25^{\circ} \mathrm{C} . \mathrm{CMC}=$ carboxymethylcellulose. Treatments included: 1 , chemo-primed, primed commercially applied fungicide-treated seed, fungicides (thiram + carboxin); 2 , primed, no fungicide applied to seed; 3 , treated, fungicide-treated seeds, no priming; 4, untreated, seed with neither fungicide treatment nor primed; 5, CMC, primed seeds coated with $1 \%$ CMC; 6 , bio-primed seeds coated with a formulation of Trichoderma harzianum $(1 \mathrm{~g})$ suspended in $1 \%$ CMC.

${ }^{\mathrm{z}}$ Means followed by the same letter are not significantly different $(P \leq 0.05)$ according to Duncan's multiple range test.

Table 2. Effects of seed treatment on mean emergence (ME), vigor index, and stand of okra at Bixby, $\mathrm{OK}$

\begin{tabular}{lllcc}
\hline & \multicolumn{2}{c}{ Stand (\%) } & & \\
\cline { 2 - 3 } Treatment $^{\mathbf{y}}$ & $\mathbf{3 \text { day } ^ { \mathbf { z } }}$ & $\mathbf{8 \text { day } ^ { \mathbf { z } }}$ & Vigor index $^{\mathbf{z}}$ & ME (days) \\
\hline Chemo-primed & $77.5 \mathrm{a}$ & $85.0 \mathrm{a}$ & $48.4 \mathrm{a}$ & 2.4 \\
Primed & $72.0 \mathrm{ab}$ & $81.0 \mathrm{ab}$ & $38.5 \mathrm{~b}$ & 2.6 \\
Treated & $67.0 \mathrm{abc}$ & $83.5 \mathrm{a}$ & $33.0 \mathrm{bc}$ & 3.2 \\
Untreated & $71.0 \mathrm{abc}$ & $77.0 \mathrm{ab}$ & $33.1 \mathrm{bc}$ & 3.1 \\
CMC & $60.0 \mathrm{bc}$ & $69.5 \mathrm{~b}$ & $37.0 \mathrm{bc}$ & 2.7 \\
Bio-primed & $59.0 \mathrm{c}$ & $70.0 \mathrm{~b}$ & $30.4 \mathrm{c}$ & 3.2 \\
LSD $(P \leq 0.05)$ & $\ldots$ & $\ldots$ & $\ldots$ & 0.6 \\
\hline
\end{tabular}

${ }^{\mathrm{y}}$ Except for the untreated control, all others were primed in clay-carri-all $(\mathrm{CCA})$ at $25^{\circ} \mathrm{C} . \mathrm{CMC}=$ carboxymethylcellulose. Treatments included: 1, chemo-primed, primed commercially applied fungicide-treated seed, fungicides, (thiram + carboxin); 2 , primed, no fungicide applied to seed; 3 , treated, fungicide-treated seeds, no priming; 4, untreated, seed with neither fungicide treatment nor primed; 5 , CMC, primed seeds coated with $1 \% \mathrm{CMC}$; 6 , bio-primed seeds coated with a formulation of Trichoderma harzianum suspended $(1 \mathrm{~g})$ in $1 \% \mathrm{CMC}$.

${ }^{\mathrm{z}}$ Means followed by the same letter are not significantly different $(P \leq 0.05)$ according to Duncan's multiple range test.
Emergence. Seedling emergence was expressed as the mean of emergence (ME) (14).

$M E=(N)+T_{2} N_{2}+\ldots+T_{n} N_{n} /$ total number of seedlings emerged

where $N=$ total number of seedlings emerged on $T=$ day number.

An index of seed vigor (11) expressed as germination vigor was also calculated.

$$
V I=\frac{G 1+G 2+\ldots+G L}{D 1+D 2+\ldots+D L}
$$

$G 1=$ number of germinants (first count)

$D 1=$ number of days to first count

$G 2$ = number of germinants (second count)

$D 2=$ number of days to second count

$G L=$ number of germinants (last count)

$D L=$ number of days to last count

All data from the experiments were converted to vigor index and $\mathrm{ME}$ values and subjected to an analysis of variance. Where appropriate, means were separated with a Duncan's multiple range test $(P \leq 0.05)$. Higher values of the vigor index indicate better vigor and lower values for ME indicate faster emergence.

\section{RESULTS}

Field trials. In general, stand at both field locations was excellent because of favorable growing conditions and little disease pressure. Chemo-primed seeds, at both locations, had faster emergence and greater seedling vigor compared to the other treatments (Tables 1 and 2).

Seedling establishment occurred during an 8-day period. Seedlings of chemoprimed seeds emerged more uniformly at both locations, and at Stillwater $92 \%$ of the stand from these seeds was established within the first 3 days. Chemo-primed seeds had greater $(P \leq 0.05)$ stand at the 3 day count compared with untreated seeds at Stillwater (Table 1). There were no differences in stand among primed, unprimed, bio-primed, CMC treated, or untreated control seeds at either location. ME values for the chemo-primed treatment were lower $(P \leq 0.05)$ than for untreated seeds. At both sites, okra was hand harvested at 2 - to 3 -day intervals (14 to 15 picks) from subplots of each treatment. There were no differences $(P \leq 0.05)$ in yield among treatments.

Pythium ultimum was consistently isolated from seedlings and soil and was the only fungus tested that was pathogenic on okra in growth chamber inoculations. Isolates of Rhizoctonia solani and Fusarium spp. from soil were weakly pathogenic in growth chamber tests. Other Pythium spp. and miscellaneous fungi (Trichoderma spp., Mucor spp., Rhizopus spp., and Chaetomium spp.) isolated from seed or soil were not pathogenic.

\section{DISCUSSION}

Seed hydration techniques were developed as early as 1919 (10) to improve the 
rate and uniformity of seed germination. Osmotic or liquid priming was developed (3) using an osmotic solution such as potassium nitrate or polyethylene glycol (PEG) to regulate imbibition of water. The water potential of the osmoticum is adjusted in such a manner to allow enough water to be imbibed by the seeds to complete pregermination metabolic activities, but to prevent the emergence of the radicle. Osmotic priming has improved the rate and uniformity of seed germination and reduced damping-off $(3,16)$. However, its utility is limited by aeration problems with seeds due to the viscous nature of PEG, phytotoxicity of some salts, large volumes of solutions needed, and problems of temperature control of the osmoticum. In order to ameliorate these problems, a new method of priming termed solid matrix priming using lignite was developed by John Eastin (7). Problems with this lignite system: Patent protection and solubility of water lead to our research to evaluate additional solid matrix substrates.

Erratic germination of okra has been reported since 1960 (1). It has been suggested $(12,16)$ that the problem of a hard seed coat of okra was reversible and an increase in the moisture content of okra seed had beneficial effects in emergence and uniformity in the field. Erratic germination and emergence of okra seed can be ameliorated by chemo-priming. Within 3 days after planting, 78 and $92 \%$ of seeds had emerged at Stillwater and Bixby, respectively, compared with 71 and $84 \%$ of the untreated controls. Chemo-primed seeds had higher vigor indices and lower mean emergence values than all other treatments. Bio-primed seeds were not as effective as chemo-primed seeds, perhaps indicating that our isolate of T. harzianum was not an effective biocontrol agent for $P$. ultimum.

The term bio-priming has been used by at least three research groups, and each group has used a different technique to achieve bio-priming. Harman and Taylor (8) added their biocontrol agents directly to the SMP, which allowed the T. harzianum to colonize the seeds during the priming process. They also achieved improved stand of tomato in Pythium-infested soil. Callan et al. (4) added a suspension of the bacterium Pseudomonas fluorescens to $1.5 \%$ methylcellulose coated, surfacesterilized sweet corn seed prior to hydrating the seeds between moistened paper towels or germination blotters. Seeds were hydrated for $20 \mathrm{~h}$, which allowed the bacterium to colonize the seed coat. This treatment protected seeds from $P$. ultimum damping-off at a level comparable to treatment with the fungicide metalaxyl. Our bio-priming treatment consisted of two steps-SMP followed by the addition of our biocontrol agent suspended in $1 \%$ $\mathrm{CMC}$ - and did not include a period of time for colonization before drying the seed. Harman and Taylor (8) noted that there was a four- to six-fold decrease in CFU per seed during the drying process.

We had noted that several SMP sources had fungal saprophytes associated with them that interfered with germination of seed after the priming process, but we found that we could eliminate these contaminating organisms by sterilizing the SMP at high temperature $\left(140^{\circ} \mathrm{C}, 24 \mathrm{~h}\right)$. We believe that one of the benefits of chemo-priming is the prevention of colonization of seed coats by saprophytic organisms which reduce seed performance during and after the priming process.

\section{ACKNOWLEDGMENTS}

Approved for publication by the Director, Oklahoma Agricultural Experiment Stations. This research was supported under project OKLO2187. Mention of a trademark, proprietary products, or vendor does not imply approval or disapproval of other products or vendors that may also be suitable. This article is a portion of a thesis submitted by the second author in partial fulfillment of the requirements for an M.S. degree at Oklahoma State University. This research was funded by the Oklahoma Center for Advancement of Science and Technology (OCAST) grant AR 2055 (Conway and Hallgren). We appreciate the donation of clays by the American Colloid Co., Arlington Heights, IL 60004, and the donation of untreated and treated okra seed by Abbott \& Cobb, 4120 West Pecan, McAllen, TX.

\section{LITERATURE CITED}

1. Anderson, W. H., Corolus, R. I., and Watson, D. P. 1960. The germination of okra seed as influenced by treatment with acetone and alcohol. Proc. Am. Soc. Hortic. Sci. 62:427432.

2. Baird, R. E., Nankam, C., Moghaddam, P. F., and Pataky, J. K. 1994. Evaluation of seed treatments on shunken-2 sweet corn. Plant Dis. 78:817-821.
3. Bradford, K. J. 1986. Manipulation of seed water relations via osmotic priming to improve germination under stress conditions. HortScience 21:1105-1112.

4. Callan, N. W., Mathre, D. E., and Miller, J. B. 1990. Bio-priming seed treatment for biological control of Pythium ultimum preemergence damping-off in sh2 sweet corn. Plant Dis. 74:368-372.

5. Conway, K. E. 1985. Selective medium for isolation of Pythium spp. from soil. Plant Dis. 69:393-395.

6. Conway, K. E., Maness, N. E., and Motes, J. E. 1997. Integration of biological and chemical controls for Rhizoctonia aerial blight and root rot of rosemary. Plant Dis. 81:795-798.

7. Eastin, J. A. 1990. Solid matrix priming of seed. U. S. patent $4,912,874$.

8. Harman, G. E., and Taylor, A. G. 1988. Improved seedling performance by integration of biological control agents at favorable $\mathrm{pH}$ levels with solid matrix priming. Phytopathology 78:520-525.

9. Khan, A. A., Abawi, G. S., and Maguire, J. D. 1992. Integrating matriconditioning and fungicidal treatment of sugar beet seed to improve stand establishment and yield. Crop Sci. 32:231-237.

10. Kidd, F., and West, C. 1919. Physiological predetermination: The influence of the physiological condition of the seed upon the course of subsequent growth and upon yield. Review of the literature. Chapter IV. Ann Appl. Biol. 6:1-26.

11. Malvasi, D., Stafford, M., and Lavender, D. P. 1985. Stratifying, partially redrying and storing douglas fir seeds: Effects on growth and germination. Ann. Sci. For. 42:371-384.

12. Marsh, L. 1993. Moisture effects cowpea and okra seed emergence and growth at low temperatures. HortScience 28:774-777.

13. Mereddy, R., Wu, L., Hallgren, S. W., and Conway, K. E. 2000. Solid matrix priming improves vigor of okra seeds. Proc. Oklahoma Acad. Sci. 80:1-5.

14. Osburn, R. M., and Schroth, M. 1989. Effects of osmopriming sugar beet seed on germination rate and incidence of Pythium ultimum damping-off. Plant Dis. 73: 21-24.

15. Rush, C. M. 1991. Comparison of seed priming techniques with regard to seedling emergence and Pythium damping-off in sugar beet. Phytopathology 81:878-882.

16. Standifer, L. C., Wilson, P. W., and Drummond, A. 1989. The effects of seed moisture content on hardseededness and germination in four cultivars of okra (Abelmoschus esculentus (L) Moench). Plant Varieties Seeds 2:149-154.

17. Van der Plaats-Niterink, A. J. 1981. Monograph of the genus Pythium. Studies in Mycology No. 21. Centtral bureau voor Schimmelcultures, Baarn, Netherlands.

18. Wu, L., Hallgren, S. W., Ferris, D. M., and Conway, K. E. 1999. Solid matrix priming to enhance germination of loblolly pine (Pinus taeda) seeds. Seed Sci. Technol. 27:251-261. 